\title{
Recent Trends in
}

\section{West German University}

\section{Library Building Planning}

\begin{abstract}
The author reviews West German university library buildings and describes five buildings completed since 1973. Some comparisons and contrasts are made between these buildings and others in West Germany built or restored between 1945 and 1973.
\end{abstract}

I N 1975 THE AUTHOR reported his observations on a visit to twenty academic libraries in the Federal Republic of Germany, built or restored after World War II. ${ }^{1}$

Five of the twenty universities had been established in this century, three of them in the postwar period. All libraries save one, at the University of Constance, kept most of their collections in architecturally separate stacks closed to readers. In the older universities, space for little-used collections was a major architectural consideration. New books were unclassified, arranged numerus currens, in order of acquisition. One authority has noted that this practice was adopted to cope with the lack of processing staff and of space after the disruption of the war period. ${ }^{2}$ Exteriors of new buildings, in contemporary style, showed considerable individuality, but the division into the three traditional units, for administration, for book storage, for readers, was often observable from the architectural as well as from the service standpoint.

Reading rooms were somewhat austere. All students sat facing one way at long narrow tables in a central reading room lined with reference books and presided over by an attendant. Typically there were high ceilings, mezzanines, and skylights. Staff members with the highest professional rank, the höhere Dienst, often held the doctorate and

Harold D. Jones is associate professor emeritus, Library Department, Brooklyn College, New York. had additionally attended library school for two years. Most of this group were Referenten, charged with responsibility for selecting books and for overseeing their classification and cataloging. They occupied pleasant offices in the administrative wing; contacts with readers appeared to be limited.

Paralleling the main library, except at Constance, on each campus one found one hundred or more seminar, institute, and laboratory libraries in classroom and laboratory buildings. They were open-access, noncirculating, classified collections maintained under the direction of chair-holding professors. One also found a few well-organized libraries of forty thousand volumes or so in a subject field such as economics or German literature. On some campuses efforts were being made at coordination through union catalogs and the work of faculty committees.

In the Federal Republic of Germany respect for the book, for scholarship, and for tradition were strong factors in library planning.

However there were signs of change. Some of the libraries placed substantial portions of their holdings on open shelves, had subject division reading rooms, and provided individual study desks, and in one case, Braunschweig, lockable individual study rooms for faculty members. Many library directors complained that in spite of book towers or storage basements their buildings were not large enough to hold growing collections. Some confided that officially appointed architects did not always listen care- 
fully to librarians' recommendations. A number expressed interest in the AngloAmerican system of flexibility, open shelves, classified collections, and concern for the reader. One stated that such interest spread among faculty members as a result of the comments of visiting professors who had taught in American universities.

The report concluded by venturing the prediction that "if librarians have their way, flexible, service-oriented buildings, standing at the center of coordinated on-campus library systems, may presently emerge."3

A second, shorter visit, following the IFLA 50th Anniversary World Congress of Librarians, in Brussels, 1977, revealed that new ideas had dominated the planning of four of the five university libraries completed since the summer of 1973 in one area of the Federal Republic, the State of North Rhine-Westphalia, and the State of Bremen, in the northwest portion of West Germany.

Fourth in area, the State of North Rhine-Westphalia is the most populous. The Freie Hansestadt Bremen, including Bremerhaven, like the cities of Hamburg and Berlin, is a state, one of eleven that constitute West Germany. The area is heavily industrialized and the demand for access to higher education following the war resulted in action by the state authorities.

The University of Münster, The Wesfälische Wilhelms- Universität, not more than thirty-eight miles from three of the four new universities, was founded in the eighteenth century. Part of its collections were inherited from the library of a Jesuit college founded in 1588.

Four of the five libraries were planned as part of new campuses located on tracts reached by public transportation from city centers in fifteen minutes or so.

\section{RUHR UNIVERSITY OF BOCHUM}

The library of the Ruhr University of Bochum is reached by an elevated walk from the highway along which the campus stretches for about three-quarters of a mile. Two parallel rows of almost identical eight-story classroom and laboratory buildings lie at right angles to the thoroughfare.

Formally opened in 1965 , it is a comprehensive university offering instruction in the liberal arts, law, medicine, theology, and en- gineering. There are twenty-five thousand students. The library building was opened in 1974.

The library, a broad open forum behind it, the auditorium (Audimax), and the food service building (Mensa) cross the main axis of the campus buildings. All structures are connected by concrete walks one floor above ground level. Parking space is provided beneath the library and the forum.

Constructed of steel and concrete, the library building appears massive and dour. The first floor, about fifteen feet above grade level, is set back to provide a covered walk. Around the central structure of the building four wings extend at every level above the main floor, supported by columns.

Entrance is from the north, facing the highway and an auxiliary campus of dormitories, shops, and a public library on the other side. There are two doorways that flank a checkroom. At one of the entrances there is a keyed elevator, which takes the administrative officers and the eleven Fachreferenten to the sixth (the top) floor, set back from the perimeter of the floors below.

A counter for book return and a checkout desk with light pen and bar graph equipment leads the visitor to the COM catalogs and to the union card catalog of the libraries of forty-three departments and institutes. (Two of these are found within the main library; the special library of the history of the labor movement, and the library of the Department of East Asian Studies). There is a reading room for German and foreign newspapers, an information desk, and on open shelves, a collection of bibliographies in the humanities and the social sciences. Unfortunately, a large part of the lighting on this floor is provided by row upon row of unfrosted incandescent lamps in clear glass globes suspended from the ceiling. There are four public elevators, two on either side, and four fire-stair towers. The floor on this level is of terrazzo.

The dominant architectural feature is the massive poured concrete stairway, that, turning at each landing, forms a great trough reaching to the top floor. Above is a skylight. At the bottom of the well is a green planter, and at night a floodlight causes it to cast upward a greenish arboreal shadow.

Each landing is surrounded by a generous and empty lobby. On bare concrete walls col- 
orful, painted, floor-to-ceiling numerals indicate the floor number and the number of each of the four reading and book areas that can be entered from the lobby.

A directory on the main floor shows that each reading and book level is divided into four color-coded zones: green, blue, red and gold. Next to this is an alphabetical listing of sixty subjects indicating floor number and area. The same data is available in the seventy-page library handbook available to all readers, as well as in a small descriptive leaflet.

A typical entrance aisle is lined with white painted wood racks providing compartments for current issues of periodicals. Signs suspended from ceilings identify the subject area. The interior portion of each zone has stacks about seven and one-half feet high; the other half, around the windows, is for readers. Directly above the shelf area is another floor for books; every other floor is a mezzanine. From reading areas they are reached by small spiral stairs, each supported on a central blue column and bordered from the outer edge of each tread by a vertical yellow two-by-four slab. All reading and book areas have thick mustard-colored carpeting.
Window panes are set into dull red metal frames. Around the perimeter are enclosed ventilator ducts about three feet high and next to them are white-topped individual study desks. Tables in rows each accommodate four readers. They are of brown metal, with light plastic tops, divided at eye level by vertical panels. From the frame above each table is suspended a covered fluorescent lamp. Unshielded fluorescent lamps in recessed troffers illuminate the entrance corridors and the shelf ranges. Chairs are of simple tubular metal construction with red orange plastic backs and seats. Wastebaskets are painted to match. There are no ceiling lights in the two-story-high reading areas. But because of the set back top floor the uppermost reading rooms have skylights.

This library, as well as the one at Constance, offers evidence that there has been a basic change in ideas and their execution in the field of academic library building planning. Most of the collections are classified and on open shelves. Readers and books are not separated. While the appearance of the bare concrete columns and walls and the striking concrete stair are austere, the use of carpeting, bright colors, and excellent

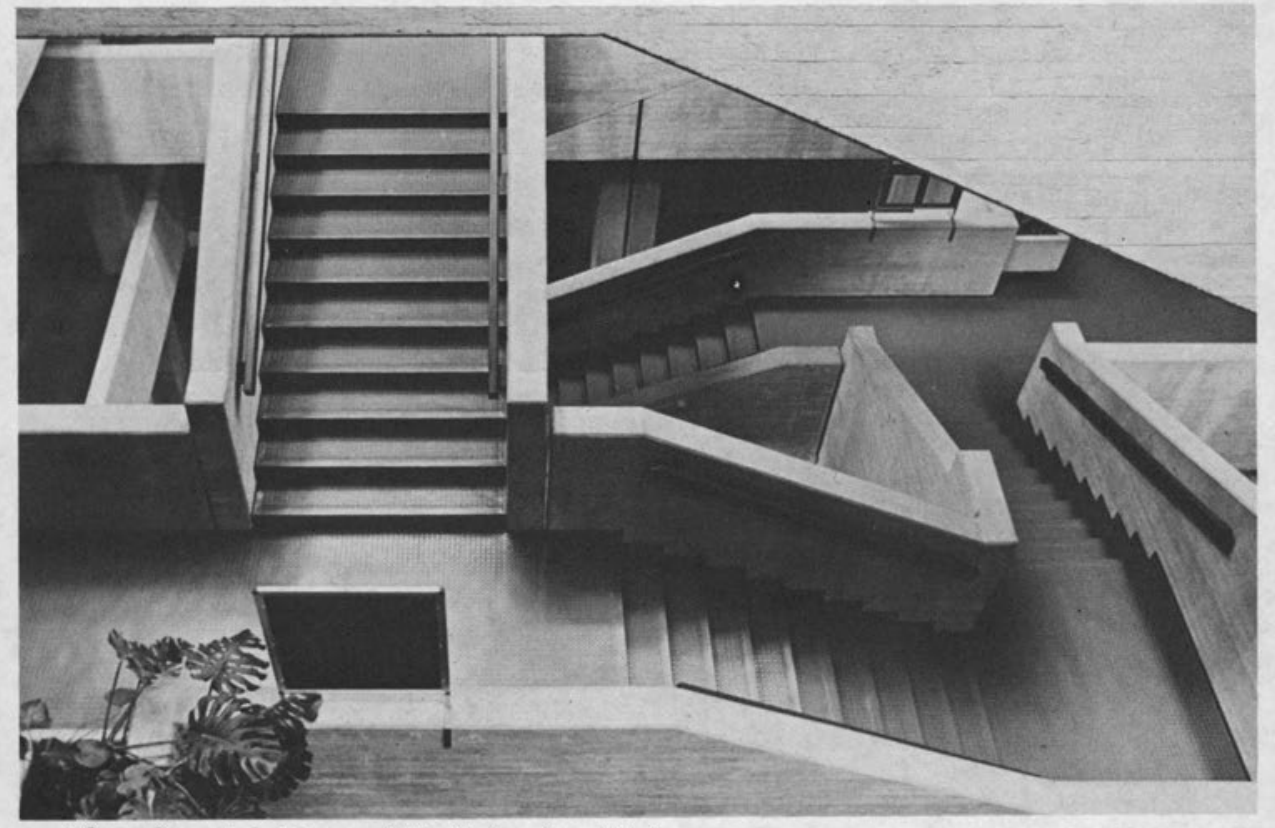

Library's central staircase, Ruhr University of Bochum. 
signage provides a feeling of amenity. A substantial portion of one zone is set aside for audiovisual services. Below the main floor is a collection of paintings, the result of gifts, housed within the library, accessible to readers at designated hours, but not directly under library administration. ${ }^{4}$

The site was a deliberate choice: "Marking the unity of research and instruction, the library lies at the center of the overall plan." It encloses about 277,000 square feet of floor area. There is space for a million and a half volumes and seats for 1,200 readers.

\section{UNIVERSITY OF DORTMUND}

The curriculum of the University of Dortmund is limited to science, technology, and social science. Classes began in 1969. The new university includes three previously existing independent institutions, the Teachers College of the Ruhr and two technical colleges (Fachhochschulen). The university library serves all constituents. The new building, replacing a temporary one, was completed in 1976. There are eleven departmental libraries in other buildings that select and catalog their own materials but operate as part of a system, with one director and one budget. Buildings on the spacious campus are in two groups, about half a mile apart. Plans call for the construction of a subway to the nearby city and then to Bochum. There are about 17,000 students.
The library is of steel and concrete, for purposes of description rectangular, though four fire towers at the corners make it octagonal. The entrance plaza is one floor above ground level. A pedestrian walk leads over the adjacent street to classroom buildings.

There is a parking lot and a street-level staff and delivery entrance. The mezzanine level extends beyond the main floor, forming an arcade. The principal book and reading floor and its mezzanine have a still wider dimension. This overhang is supported by narrow exterior square columns three stories high. The windows of the upper mezzanine are protected by a horizontal concrete sun shield. A copper-clad sloped roof on one side adds to the building's distinctive appearance as do plastic orange window blinds which protect the ground floor on the opposite side. The fire towers are of off-white concrete. Other exterior surfaces are of cinnamon brown aggregate. There is a shed roof to provide daylight for the top mezzanine floor and for the reading areas of the floor below.

The building design was the result of a competition. The director states that he had considerable voice in planning. The basic service plan is like Bochum's. Once inside, after passing a checkpoint, the reader has access to virtually all areas.

On the first floor, which because of a mezzanine is in part two-storied high, there is near the main entrance a tiered floor audito-

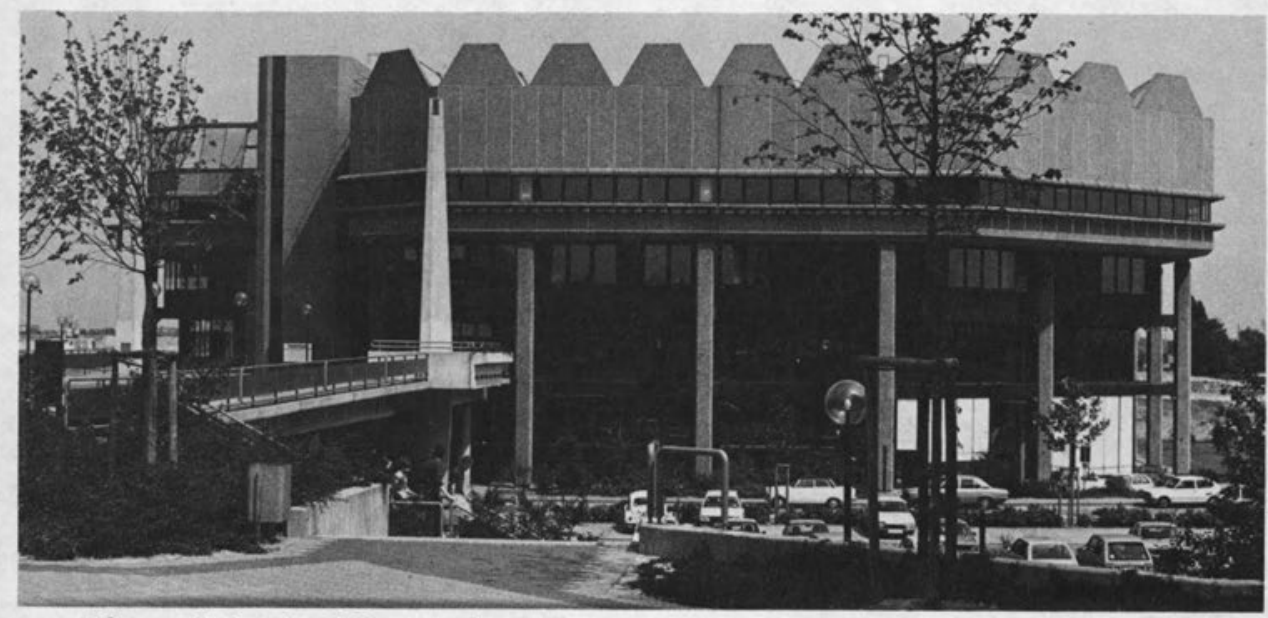

Library, University of Dortmund.

Universitatsbibliothek Dortmund 
rium enclosed in brick. The outer walls are used to display colorful prints. There is also the checkroom area always found in German university libraries. The lockers and coat hangers are painted a cheerful red. To the right of the entrance is the current newspaper reading room. After passing the circulation desk one has access to the card catalog, the textbook collection, and the currentperiodicals reading room. The latter is surrounded by glass walls.

Centrally located are two elevators for readers, and the main stairway. The first level above is a mezzanine. Here one sees a detailed directory and behind it the glass front walls and the tall windows of the offices of nine Fachreferenten, the director, and his deputy. There is a conference room, a staff lounge, and large areas for technical services.

The third level looks much like a floor in any newly built American university library. Range after range of classified volumes are on open shelves, and around the perimeter next to the windows, reading areas. There is a central core of stair and elevators, public facilities and copying machines, and a Telelift station. This book-moving device uses a wheeled container about the size of a weekend case which moves on tracks that extend horizontally or vertically, straight or around curves. Shelf areas are illuminated by fluorescent lamps in troffers suspended from the ceiling between the ranges.

The top floor is also for books and readers. There are wells cut through to the reading areas below to give them the advantage of daylight illumination from the shed roof. This top floor is of lighter construction as the bookshelves are supported by the ranges below. The upper level may be reached directly from the reading areas below by means of spiral stairs painted red with a yellow border.

Ventilation is provided through round, exposed metal ducts painted red and suspended from the ceiling around main floors at the perimeter. Interior walls in reading areas are bright red and gray. Reading tables seat two, side by side. Their red tubular front legs continue upward arching over the tables at a height of about four feet to suspend covered fluorescent lamps over the white plastic table tops.

The basement provides space for patentoffice material, more than two million items on see-through punched cards, a storage area, binding, and photography. A lower level, as yet unoccupied, provides space for future growth.

This is a fine, modular building. The carpeting is a colorful red and yellow and very cushiony. Interior walls and columns are painted. There are six hundred seats and space for a million volumes. Library staff members, working with the university administration and IBM specialists, have developed plans for computer applications. ${ }^{6}$

\section{UNIVERSITY OF BIELEFELD}

The University of Bielefeld was established in 1969 as the result of public demand for a university in eastern Westphalia. The entire campus design was the result of a competition. It resembles no other campus ever visited by this author. Except for a few subordinate structures and a massive parking garage, there is one single enormous building, a citadel. Around a central two-story hall, measuring 790 feet long and 69 feet wide, are the public places of a small community, the dining facility, a savings bank, travel bureau, drug store, coffee shop, post office, and a bookstore. The pitched roof is of glass, giving the appearance of a greenhouse. Crossing the hall at the mezzanine level are three bridges, each bearing directional signs. At one end is the entrance to the swimming pool and at the other an auditorium with 1,475 seats. Planted areas and skylights surround the glass roof. The entire central structure is bordered by two parallel slab buildings of concrete and glass, about eight stories high, for classrooms, offices, and laboratories. Connected to these and extending from them like the teeth of a comb, are, on one side five and on the other side four classroom, office, and laboratory buildings from seven to ten stories high.

Entrance to library areas is on the mezzanine level. It has a central administrative office, a general reference area, an office for interlibrary loans, and the technical-service areas. The reading and book areas are divided among five separate spaces that house three science and seven humanities and social science collections. Books are classified and on open shelves. Each of the five areas has its own bar code and light pen checkout system. There are COM catalogs. Carpeting is of an 
unobtrusive gray. There are massive exposed vertical and horizontal ventilation ducts and a great deal of daylight provided by skylights and tall windows. Some of the libraries occupy two floors. Due to oversight, or for reasons of economy, none of the library areas have their own elevators. Current and recent unbound periodicals are kept in tall banks of metal containers looking like oversize safedeposit boxes, save for the fact that their hinged doors colorfully identify the items within by means of titles clipped from covers of back issues and pasted on, providing a varying typographic display. Stair rails, window frames, and some columns are painted a subdued red. Reading tables with white tops are placed two by two to provide seats for eight readers. Single fluorescent lamps in egg-crate troffers hang at right angles to the bookshelves from ten-foot-high ceilings. In the sociology collection there is a separate room for the Human Relations Area Files, and there is a Mediothek, a small area well stocked with cassettes, reel-to-reel tapes, slides, and copies of standardized texts for use by future teachers. The subject specialists, the Fachreferenten, have pleasant offices. As in other university libraries in West Germany, there are clear attractive signs and color-coded plans to help the reader.

\section{WESTPHALIAN WILHELMS UNIVERSITY OF MÜNSTER}

A sketch made in 1740 shows a precursor of the new library building of the Westphalian Wilhelms University of Münster. It was a baroque, high-ceilinged rectangular hall with a shallow mezzanine. Book shelves were placed around the walls between tall windows. This space constituted a wing of the Jesuit college on the cathedral square.

Deprived of and then restored to university status in 1902, the institution built a new library in an L-shaped Renaissance building. This was substantially damaged in World War II. Rebuilt, enlarged, and reorganized by 1951 , the new structure was unable to cope with the demands of a rapidly developing university, a growing book collection, and the onrush of readers. Nearby in the old city, a private residence was purchased and plans for a new library were developed. The new building was opened to readers at the end of 1973.
The new library site was triangular, located near the old palace occupied by the university administration and not far from the humanities center and the old library, now housing the law school and its library. To provide maximum daylight, a major consideration in German academic library building planning, the library is T-shaped, a pleasing brick structure, banded by wide, blue-tinted windows in aluminum frames. The stem of the $\mathrm{T}$ is three stories high, the crossbar two. Intersecting the upper left-hand corner of the latter is a small two-story wing. A two-level basement extends under the plaza. The main entrance is reached by passing a bike park, mounting a short flight of stairs from the narrow street, crossing a pleasant plaza of exposed aggregate, and entering one flight above grade level. A light-moat illuminates part of the basement. Behind the library the river Aa flows quietly between concrete banks.

On the left of the entrance hallway one finds the inevitable Garderobe with selfservice lockers. The textbooks collection is nearby. Passing a checkpoint and turnstiles, one sees an information desk and open stairway and elevators, and in the center of each wing a section of the card catalog. A union catalog of all scholarly collections in the city of Münster is in an enclosed area. The interlibrary loan office, rooms for acquisitions and cataloging, and twelve offices for Fachreferenten border the public catalog area.

The open stair leads to the main reading and book area, with space for more than four hundred readers. The open-shelf collection is arranged by subject. There is combined conference and exhibit area. On the much smaller third floor there are the manuscript, the map, and the music-listening departments. Bound periodicals are on open shelves down the center of the room. There are twelve partially enclosed individual study spaces and four group study rooms.

The total area of the building is about 121,000 square feet. Book capacity is $1,400,000$ volumes and there are seats for 650 readers. ${ }^{7}$ The director pointed out that compact storage, used in many libraries in the Federal Republic, is too expensive for seldom-used books and too cumbersome for the active collection. The basement storage areas, however, are equipped with battery- 
powered you-drive-it carts with book baskets over the rear axle and couplings that can be used for pulling book trucks.

Surface-mounted lighting fixtures in the public areas each enclose four short fluorescent tubes in a green frame. The wool upholstered chair backs, selected by staff members, match the borders of the lighting fixtures. Carpets are beige. Narrow tables, with readers all facing one way, have light plastic tops and black tubular legs. At several points there are groups of informal seats covered in red plastic.

The director declares this to be an oldfashioned library in that there are 140 departmental libraries over which he has no control, and the older works, in closed stacks, are arranged numerus currens. Nevertheless one observes that the Referenten, while not continuously interacting with readers, have their offices near the public catalogs. The technical-service offices are adjacent. Structurally the building is flexible and modular, with permanent interior walls surrounding only the stairs and other utilities.

All areas, save a portion of the administrative offices, are air-conditioned. The IBM circulation system can indicate whether or not a book is shelved in the basement stacks. Behind the circulation desk is a numbered diagram showing the ceiling areas through- out the building. By using the colorful array of push buttons the person on duty can control the lights. There are drapes on the heatresistant windows and, here and there, planters. The ceiling on the main floor is somewhat higher than on those above and below. Old-fashioned or not, there is no feeling of regimentation and much evidence of careful planning and regard for readers.

\section{UNIVERSITY OF BREMEN}

From outside and within, the library building of the University of Bremen resembles American university libraries built in recent decades. Five stories high and almost square (about 230 by 260 feet), it has 275,000 square feet, gross, of floor area. It provides open access to range after range of classified volumes on open shelves surrounded by individual study desks and carrels. The framing is of steel and bare concrete on a module of 23.6 square feet (i.e., 7.2 meters). There are also a few group studies and smoking lounges. Only in the number of seats does it differ in appearance from academic libraries in the United States. There are 800 , about one for every twelve students.

Early in the planning phase it was decided that there should be on this new campus a library system with a relatively large central library and only five departmental libraries

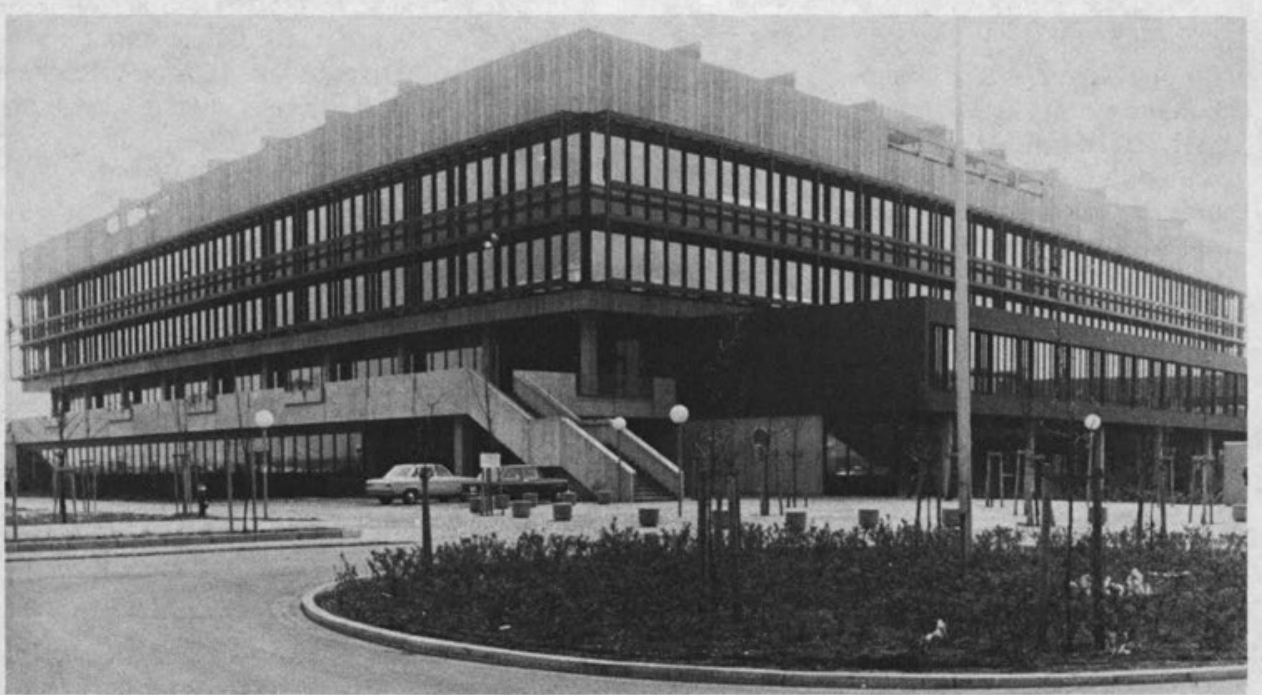

University of Bremen library: view from the north, showing entrance for personnel and delivery section for suppliers. 
in other buildings. There are no independent seminar or institute libraries.

The director, well known for his views on the relationship between library organization and library architecture, reports close collaboration between himself and the architect, stating that the practicality of his convictions were confirmed by a visit to campuses in the United States. ${ }^{8}$

Because of a high water table and sandy soil there is no basement. The main floor is about fifteen feet above grade level, reached by a pedestrian walk over the adjacent street, leading to and from other university buildings. Set back, it forms a covered walk around the structure, protecting the windows of the main floor from direct sunlight. The two main book and reading floors are banded by large windows framed in black metal. Exterior to them is a metal framework for the window cleaner's car. At each level there are metal louvers above the panes.

On two sides there are two extensions to the main floor and basement. In one, adjacent to the street, are the rooms for mail, binding and book repair, for gifts and exchange, and photography. Above on the main floor are the offices for acquisitions and cataloging. On the opposite side of the building, past the main entrance, is a multipurpose meeting room and auditorium, with seats for 336 , a projection booth, a chair storage area, and a serving pantry. At ground level is storage space and high-tension electrical equipment.

When the university was founded it was decided that its new library would take over the collection and the responsibilities of the state library of Bremen. Many of the older books are housed on the ground-floor level. The installation of compact shelving will increase the capacity of the building to about two million volumes. To expedite movement of books on this floor there is an overhead conveyor belt. A Telelift system carries books to and from service points on all floors.

To the right of the main entrance lobby is the checkroom and an exit of one of the four fire stairs. Directly ahead is the circulation desk where bar graph and light pen equipment is used. On the right are the catalog cases, an extensive textbook collection, and farther on, near the main stair and elevators, the information desk. To the left, accessible from the acquisition offices, is the conference room where the Referenten meet to discuss what titles are to be ordered. On the side furthest from the entrance are the offices of the director and his associates.

Arriving on floor two, one sees an information desk, COM catalogs, public facilities, a lounge, a room with copying equipment, and individual study rooms. There are directional signs suspended from the ceiling. Around the perimeter on three sides are individual study desks and group and individual study rooms. Along the wall on the fourth side and connected by elevator to the acquisitions and cataloging offices are the offices of the Fachreferenten who are expert in the subject fields represented by the collections on this floor. The floor above is similar, with clearly indicated subject areas.

The top floor, set back one module, is for audiovisual services and for special collections. In addition to staff and work rooms there are facilities for individual and for group listening to tapes and disks. There is an enclosed area for manuscripts, incunabula, and other rarities. Most of the open shelves are occupied by a special collection of newspapers, current and historic. Bremen has a special responsibility in this area for collection building and research (Presseforschung). There is also a special collection on the history of Bremen (Bremensien). The offices of Fachreferenten are nearby. The setback provides for an attractively designed outdoor roof garden, and there is a lounge where smoking is permitted.

\section{ConClusion}

Ideas about the organization and planning of university libraries in the Federal Republic of Germany have changed in recent decades and the new buildings offer evidence of the change. Books are classified, arranged by subject on open shelves, and accessible to readers. In only one out of five examples is the two-track system of central university library and one hundred or more independent seminar or institute collections perpetuated. On three campuses the director is head of a system of a limited number of departmental collections. In four out of five the subject specialists and the administrative officers are not sequestered in architecturally separate spaces. There are storage basements but no 
book towers. Lighting levels seem higher, public areas are carpeted, and the use of color and a choice of seating accommodations suggest that the traditional air of austerity, earlier noted, is a thing of the past. The offices of Fachreferenten are accessible to readers.

Other university library buildings have recently been completed in West Germany.
Several are under construction and others are being planned. Each will have distinctive characteristics. One may look with interest for basic trends that indicate that the theory and practice of university library building planning and operation are under continuous revision.

\section{REFERENCES}

1. Harold D. Jones, "Postwar University Library Buildings in West Germany," College \& Research Libraries 36:283-94 (July 1975).

2. Gisela Von Busse and Horst Ernestus, Libraries in the Federal Republic of Germany (Chicago, American Library Assn., 1972), p.202.

3. Jones, "Postwar University Library," p.294.

4. "Neuerwerbungen der Kunstmuseen in Nordrhein-Westfallen 1974," Wallraf-Richartz Jahrbuch 37:289-307 (1975).

5. Gerhard Liebers, Bibliotheksneubauten in der Bundesrepublic Deutschland Zeitschrift für Bibliothekswesen und Bibliographie, Sonderheft 9 (Frankfurt am Main: Klosterman, 1968), p.55 (Author's translation).
6. Barbara Jedwabski, "Dobis-Ein Integriertes On-line Bibliotheksystem," in Valentin Wehefritz, ed., 10 Jahre Universitätsbibliothek Dortmund (Dortmund: Gesellschaft Der Freunde Der Universität Dortmund, 1975), p.16-29.

7. Gerhard Liebers, "Das Neue Haus der Universitätsbibliothek Münster," DFW Dokumentation Information 24 Jahrgang, 1975 (Sonderheft zum 66 Deutschen Bibliothekartag 1976 in Münster), p.3.

8. Rolf Kluth, "Neubau der Zentralen Bibliothek der Universität Bremen," Neubau der Zentralbibliothek, Eine Einführung (Bremen: Universität Bremen, Informations Abteilung, 1976), p.3. 